\title{
Penentuan Besaran Uang Kuliah Tunggal untuk Mahasiswa Baru di Universitas Sam Ratulangi Menggunakan Data Mining
}

\author{
Budianto Karim ${ }^{1)}$, Steven R. Sentinuwo ${ }^{2)}$,Alwin M. Sambul ${ }^{3)}$ \\ 1,2,3 Program Studi Teknik Informatika, Fakultas Teknik, Universitas Sam Ratulangi \\ E-mail : 120216053@ student.unsrat.ac.id ${ }^{1)}$, steven@unsrat.ac.id ${ }^{2)}$, asambul@unsrat.ac.id ${ }^{3}$
}

\begin{abstract}
Abstrak -Pemerintah melalui Kementerian
Pendidikan dan Kebudayaan mengeluarkan peraturan Nomor 55 Tahun 2013 tentang Biaya Kuliah Tunggal dan Uang Kuliah Tunggal pada PTN di lingkungan Kemendikbud. Penentuan UKT dilakukan dengan wawancara dan mengisi formulir yang disediakan oleh pihak kampus. Pada saat penerimaan Mahasiswa barupihak kampus akan mengalami kesulitan dan memerlukan waktu yang cukup lama dalam menentukan kategori UKT yang tepat karena jumlah mahasiswa yang begitu banyak. Oleh karena itu, dengan menggunakan teknik data mining akan mempermudah dalam penetapan kelompok UKT dengan menerapkan algoritma $\mathrm{C} 4.5$ dengan delapan parameter sebagai inputan yang diambil dari data mahasiswa. Pada penelitian ini dilakukan dua percobaan, untuk percobaan pertama dilakukan dengan jumlah data 80 dengan hasil akurasi sebesar 50\% dan percobaan kedua dengan jumlah data 115 dengan hasil akurasi sebesar 52,63\%. Dari penelitian tersebut diketahui jumlah data sangat berpengaruh dalam hasil pengujian.
\end{abstract}

Kata kunci :UKT, Data mining, Algoritma C4.5.

\section{PENDAHULUAN}

Kuliah merupakan proses pembelajaran tingkat lanjut untuk membentuk diri dalam meningkatkan ilmu, wawasan, minat dan bakat serta kemampuan seseorang dengan pilihan jurusan atau keahlian yang diinginkan. Tetapi, untuk mengenyam pendidikan tinggi diperlukan perencanaan keuangan untuk biaya perkuliahan. Setiap universitas dan fakultas berbeda-beda dalam penetapan uang pangkal dan setiap tahunnya mengalami kenaikan.Oleh karena itu, Pemerintah melalui Direktorat Jendral Pendidikan Tinggi Kementerian Pendidikan dan Kebudayaan mengharuskan setiap perguruan tinggi negeri meniadakan uang pangkal perkuliahan.

Kebijakan ini mengacu kepada Peraturan Menteri Pendidikan dan Kebudayaan Republik Indonesia Nomor 55 Tahun 2013 tentang Biaya Kuliah Tunggal dan Uang Kuliah Tunggal pada Perguruan Tinggi Negeri di Lingkungan Kementerian Pendidikan dan Kebudayaan.
Melihat pada pasal 1 ayat 3 yang berbunyi, "Uang kuliah tunggal merupakan sebagian biaya kuliah tunggal yang ditanggung setiap mahasiswa berdasarkan kemampuan ekonominya". Biaya kuliah tunggal merupakan seluruh biaya operasional per mahasiswa per semester pada program studi di perguruan tinggi negeri dan uang kuliah tunggal (UKT) ditetapkan berdasarkan biaya kuliah tunggal dikurangi dengan biaya yang ditanggung oleh pemerintah. Dengan itu, Mahasiswa baru cukup membayar uang kuliah tunggal disetiap semesternya dan tidak perlu lagi membayar biaya-biaya lainnya seperti biaya praktikum, yudisium, kuliah kerja nyata, wisuda dan lain sebagainya. Namun, akan muncul rasa ketidakadilan jika dilihat dari sudut pandang besaran biaya yang harus dibayar oleh mahasiswa yang kondisi ekonominya menengah keatas dengan mahasiswa yang kondisi ekonominya menengah kebawah dan akan menimbulkan kesan program studi mahal dan program studi murah.

UKT bertujuan untuk membantu orang yang kurang mampu, artinya subsidi silang. Pada kenyataannya di lapangan, masih banyak mahasiswa dengan kondisi ekonomi lemah dikenai UKT dengan tarif tinggi dan begitupun sebaliknya. Penentuan golongan UKT dilakukan dengan wawancara dan mengisi formulir yang disediakan oleh pihak kampus pada saat pendaftaran kembali, lalu diverifikasi. Ini menjadi permasalahan yang baru ketika mulai memasuki masa penerimaan mahasiswa baru. Mengingat jumlah mahasiswa yang begitu banyak, pihak universitas akan kesulitan dan memerlukan waktu yang cukup lama untuk menentukan kategori yang tepat dalam penetapan UKT pada setiap mahasiswa.

Untuk membantu penetapan kategori yang tepat pada setiap mahasiswa, dapat digunakan pendekatan Data Mining dengan algoritma tertentu. Dimana, Data Mining merupakan suatu proses untuk menemukan informasi yang bermanfaat dari sekumpulan data yang besar. Ada beberapa faktor yang mempengaruhi penetapan UKT tersebut, antara lain kondisi orang tua, pendidikan orang tua, pekerjaan orang tua, penghasilan orang tua, jumlah tanggungan, dan kepemilikan rumah. Jadi, dari kumpulan data historis penulis dapat menetapkan UKT bagi 
mahasiswa baru yang diterima di Universitas Sam Ratulangi.

\section{LANDASAN TEORI}

\section{A. Uang Kuliah Tunggal}

Uang Kuliah Tunggal atau disingkat UKT menurut Peraturan Menteri Pendidikan dan Kebudayaan Republik Indonesia Nomor 55 Tahun 2013, “Uang kuliah tunggal merupakan sebagian biaya kuliah tunggal yang ditanggung setiap mahasiswa berdasarkan kemampuan ekonominya" [9]. Uang kuliah tunggal sebagaimana yang dimaksud terdiri atas beberapa kelompok yang ditentukan berdasarkan kelompok kemampuan ekonomi masyarakat. Uang kuliah tunggal ini ditetapkan berdasarkan biaya kuliah tunggal dikurangi biaya yang ditanggung oleh pemerintah.

Biaya kuliah tunggal adalah keseluruhan biaya operasional permahasiswa per semester pada program studi di perguruan tinggi negeri. Dimana, biaya kuliah tunggal ini digunakan untuk menetapkan biaya yang dibebankan kepada mahasiswa masyarakat dan pemerintah. Dengan diberlakukan UKT ini, perguruan tinggi negeri tidak dibolehkan memungut uang pangkal atau pungutan lainnya dari mahasiswa baru yang telah diterima diperguruan tinggi tersebut.

\section{B. Data Mining}

Menurut Han[5], Data Mining adalah proses menemukan pola dan pengetahuan dari sejumlah data yang besar. Menurut Siallagan[11]Definisi Data Mining adalah:

a. Mengekstrak atau "mining" pengetahuan darikumpulan data yang sangat besar.

b. Data yang diekstrasi menjadi informasi yang berguna, dimana tidak diharapkan, tidak dikenal dan implisit.

c. Eksplorasi \& analisis, dari sekumpulan data yang sangatbesaruntuk memperoleh pola-pola data yang berartisecara otomatis atau semiotomatis.

d. Menemukan pola yang valid, baru, berguna dan dapat dipahami manusiamelalui proses analisis database yang besar secara semiotomatis.

Menurut Prasetyo[7] pengertian data mining secara naratif mempunyai beberapa maksud:

- Pencarian otomatis pola dalam basis data yang besar, menggunakan teknik komputasional campuran dari machine learning,statistik, dan pengenalan pola.

- Pengekstrakan implisit non-tivial, yang sebelumnya belum diketahui secara potensial adalah informasi berguna dari data.

- Ilmu pengekstrakan informasi yang berguna dari set data atau basis data besar.

- Eksplorasi otomatis atau semiotomatis dan analisis data dalam jumlah besar, dengan tujuan untuk menemukan pola yang bermaksna.
- Proses penemuan informasi otomatis dengan mengidentifikasi pola dan hubungan "tersembunyi" dalam data.

C. Metode Decision Tree

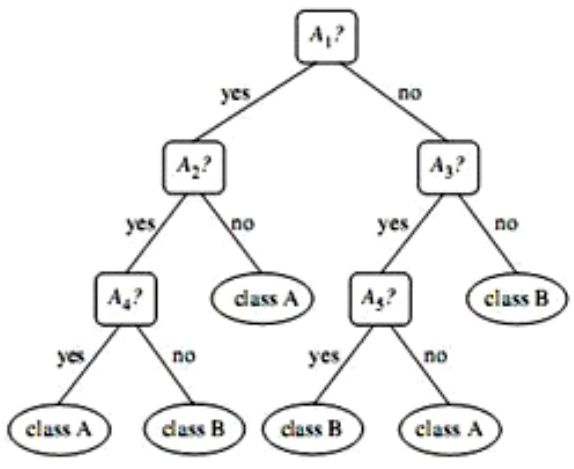

Gambar 1. Pohon Keputusan

Decision Tree atau pohon keputusan adalah pohon yang digunakan sebagai prosedur penalaran untuk mendapatkan jawaban dari masalah yang dimasukkan. Pohon yang dibentuk tidak selalu berupa pohon biner. Jika semua fitur dalam data set menggunakan 2 macam nilai kategorikal maka bentuk pohon yang didapatkan berupa pohon biner. Jika dalam fitur berisi 2 macam nilai kategorikal atau menggunakan tipe numerik maka bentuk pohon yang didapatkan biasanya tidak berupa pohon biner[7].

Metode ini merupakan salah satu metode yang ada pada teknik klasifikasi dalam data mining. Metode pohon keputusan mengubah fakta yang sangat besar menjadi pohon keputusanyang merepresentasikan aturan. Pohon keputusan juga berguna untuk mengekplorasi data, menemukan hubungan tersembunyi antara sejumlah calon variabel input dengan sebuah variabel target[1].

Decisiontree adalah metode diskrimasi nonlinearyang menggunakan sekumpulan variabel independenuntuk membagi sampel ke dalam kelompok-kelompok yang lebih kecil secara bertahap. Prosedur tersebutdilakukan secara iterative di setiap cabang pohon, yaknimemilih variabel independen yang memiliki asosiasi terkuat dengan variabel dependen menurut kriteriatertentu.

Menurut Prasetyo[7], Decision Tree mempunyai tiga pendekatan klasik:

1) Pohon klasifikasi, digunakan untuk melakukan prediksi ketika ada data bau yang belum diketahui label kelasnya. Pendekatan ini yang paling banyak digunakan.

2) Pohon regresi, ketika hasil prediksi dianggap sebagai nilai nyata yang mungkin akan didapatkan. Misalnya kasus harga minyak, kenaikan harga rumah, prediksi inflasi tiap tahun dan sebagainya.

3) CART (atau C\&RT), ketika masalah klasifikasi dan regresi digunakan bersama-sama.

Ada banyak pilihan algoritma untuk menginduksi decision tree, seperti Hunt, CART (C\&RT), ID3, C4.5, SLIQ, SPRINT, QUEST, DTREG, THAID, CHAID, dan sebagainya. 
D. Algoritma $\mathrm{C} 4.5$

Algoritma C4.5 diperkenalkan oleh Quinlan (1996) sebagai versi perbaikan dari ID3. C4.5 adalah algoritma yang sudah banyak dikenal dan digunakan untuk klasifikasi data yang memiliki atribut-atribut numerik dan kategorial. Hasil dari proses klasifikasi yang berupa aturan-aturan dapat digunakan untuk memprediksi nilai atribut bertipe diskret dari record yang baru[8].

Algoritma C4.5 merupakan suskesor dari ID3 menggunakan rasio gain untuk memperbaiki information gain. Rasio gain merupakan normalisasi dari information gain dengan memperhitungkan nilai entropy dari probabilitas subset setelah dilakukan proses partisi. Atribut dengan nilai rasio gain tertinggi dipilih sebagai atribut node akar[6].

Secara sistematis, rasio gain dihitung dengan persamaan 2.1 berikut:

$$
\operatorname{RasioGain}(\boldsymbol{S}, \boldsymbol{A})=\frac{\operatorname{Gain}(S, A)}{\operatorname{SplitInfo}(S, A)}(1)
$$

Dimana:

$\begin{array}{ll}S & =\text { Himpunan Kasus } \\ A & =\text { Atribut } \\ \operatorname{Gain}(S, A) & =\text { Gain pada atribut } A \\ \operatorname{Split} \operatorname{Info}(S, A) & =\text { Split Info atribut } A\end{array}$

Split info merupakan entropy dari seluruh distribusi probabilitas subset setelah dilakukan pemartisian (splitting).

$$
\operatorname{SplitInfo}(\boldsymbol{S}, \boldsymbol{A})=-\sum_{i=1}^{n} \frac{p_{i}}{S} \times \log _{2} \frac{p_{i}}{S}(2)
$$

Dimana:

$S=$ Himpunan Kasus

$A=$ Atribut

$n=$ Jumlah partisi atribut $A$

$p_{i}=$ Jumlah dari atribut $A_{i}$

\section{E. Confusion Matrix}

Confusion matrix adalah suatu metode yang digunakan untuk melakukan perhitungan akurasi pada konsep data mining.Evaluasi menggunakan confusion matrix menghasilkan nilai accuracy, recall dan precision.Akurasi dalam klasifikasi adalah presentase ketepatan record data yang diklasifikasikan secara benar setelah dilakukan pengujian pada hasil klasifikasi.Recall merupakan jangkauan algoritma terhadap nilai yang sebenarnya, sedangkan precision merupakan ketepatan algoritma terhadap nilai yang telah ditemukan algoritma[12].

Tabel 1. Model Confusion matrix

\begin{tabular}{|c|c|c|}
\hline \multirow{2}{*}{$\begin{array}{c}\text { Nilai } \\
\text { prediksi }\end{array}$} & \multicolumn{2}{|c|}{ Nilai sebenarnya } \\
\cline { 2 - 3 } True & True & False \\
\hline \multirow{2}{*}{ False } & $\begin{array}{c}\text { (True Positive) } \\
\text { Correct Result }\end{array}$ & $\begin{array}{c}\text { FP } \\
\text { (False Positive) } \\
\text { Unexpected Result }\end{array}$ \\
\hline \multicolumn{2}{|c}{ FN } \\
\hline
\end{tabular}

\begin{tabular}{|l|c|c|}
\hline & $\begin{array}{c}\text { (False Negative) } \\
\text { Missing Result }\end{array}$ & $\begin{array}{c}\text { (True Negative) } \\
\text { Correct Absence of } \\
\text { Result }\end{array}$ \\
\hline
\end{tabular}

Keterangan untuk tabel 1dinyatakan sebagai berikut:

1. True Positive (TP), yaitu jumlah dokumen dari kelas true yang benar dan diklasifikan sebagai kelas true.

2. True Negative (TN), yaitu jumlah dokumen dari kelas false yang benar diklasifikasikan sebagai kelas false.

3. False Positive (FP), yaitu jumlah dokumen dari kelas false yang salah diklasifikasikan sebagai kelas true.

4. False Negative (FN) yaitu jumlah dokumen dari kelas true yang salah diklasifikasikan sebagai kelas false.

Perhitungan akurasi dinyatakan dalam persamaan 3

$$
\text { accuracy }=\frac{T P+T N}{T P+F N+F P+T N} \times 100 \%(3)
$$

Perhitungan recall dinyatakan dalam persamaan 4

$$
\text { recall }=\frac{T P}{T P+F N}(4)
$$

Perhitungan precision dinyatakan dalam persamaan 5

$$
\text { presicion }=\frac{T P}{T P+F P}(5)
$$

\section{F. RapidMiner}

RapidMiner merupakan perangkat lunak yang bersifat open source. RapidMiner adalah sebuah tools untuk melakukan analisis terhadap data mining, text mining dan analisis prediksi. RapidMiner dibangun dengan menggunakan Bahasa java, sehingga dapat dijalankan di semua sistem operasi. RapidMiner sebelumnya bernama YALE (Yet Another Learning Environment) yang dikembangkan pada tahun 2001 oleh RalfKlinkenberg, Ingo Mierswa, dan Simon Fischer di Artificial Intelligence Unit dari University of Dortmund [3].

Beberapa Fitur dari RapidMiner, antara lain:

- Banyaknya algoritma data mining, seperti decision tree dan self-organization map.

- Bentuk grafis yang canggih, seperti tumpang tindih diagram histogram, tree chart dan $3 D$ Scatter plots.

- Banyaknya variasi plugin, seperti text plugin untuk melakukan analisis teks.

- Menyediakan prosedur data mining dan machine learning termasuk: ETL (extraction, transformation, loading), data preprocessing, visualisasi, modelling dan evaluasi.

- Proses data mining tersusun atas operator-operator yang nestable, dideskripsikan dengan XML, dan dibuat dengan GUI

- Mengintegrasikan proyek data mining Weka dan statistika R 


\section{METODOLOGI PENELITIAN}

\section{A. Data Penelitian}

Data penelitian diambil dari 115 data kuisioner yang dibagikan kepada mahasiswa Universitas Sam Ratulangi dengan kriteria mahasiswa angkatan 2013-2016. Data yang diambil antara lain : Kondisi Ayah, Pendidikan Ayah, Pekerjaan Ayah, Penghasilan Ayah, Kondisi Ibu, Pendidikan Ibu, Pekerjaan Ibu, Penghasilan Ibu, Jumlah Tanggungan, Status Kepemilikan Rumah dan UKT.

\section{B. Tahapan Penelitian}

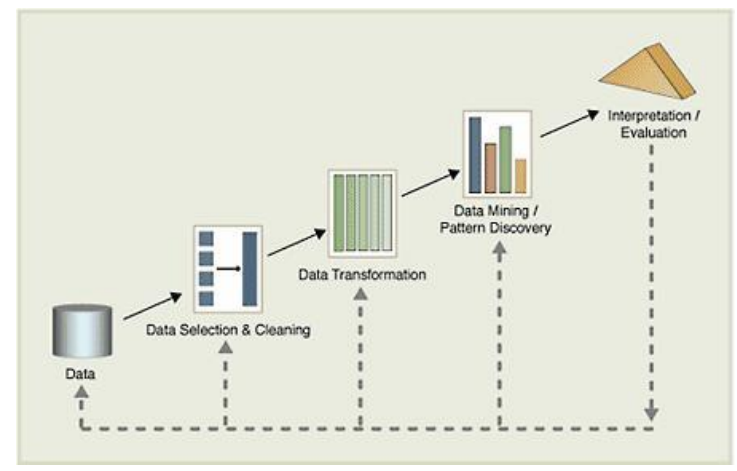

Gambar 2. Tahap-tahap Data Mining

Sebagai suatu rangkaian proses, data mining dapat dibagi menjadi beberapa tahap proses yang diilustrasikan pada Gambar 2. Tahap-tahap tersebut bersifat interaktif, dan pemakai terlibat langsung atau dengan perantaraanknowledgebase.

Proses data mining ini terdiri dari :

1) Data Selection \& Cleaning: Pembersihan data merupakan proses mnghilangkan noise, menghilangkan duplikasi data dan menghilangkan data yang tidak konsisten atau data yang tidak relevan. Data yang ada pada database sering kali tidak semuanya dipakai, oleh karena itu hanya data yang sesuai untuk dianalisis yang akan diambil dari database. Pada penelitian ini data yang dihilangkan adalah kolom NIM, Tahun Lulus, Status Anak, Jenis Lantai, Bahan Tembok, Listrik dan Ukuran Bangunan karena tidak akan digunakan dalam proses mining.

2) Data Transformation: Pada proses ini data diubah atau digabung ke dalam format yang sesuai untuk diproses dalam data mining. Dalam hal ini data yang telah selesai akan disimpan dengan format .csv. Untuk kelasnya terdiri dari Rp.0 -
Rp.3.000.000 (Kelompok 1), >Rp.3.000.000 -

Rp.5.000.000 (Kelompok 2), >Rp.5.000.000 -

Rp.7.000.000 (Kelompok 3), >Rp.7.000.000 -

Rp.11.000.000 (Kelompok 4), >Rp.11.000.000

(Kelompok 5).

3) Data Mining: Proses mining merupakan suatu proses utama saat metode diterapkan untuk menemukan pengetahuan berharga dan tersembunyi dari data. Pemilihan motode atau algoritma yang tepat sangat bergantung pada tujuan dan proses secara keseluruhan. Hasil dari transformasi data kemudian dianalisa untuk mendapatkan model yang terbentuk sebagai pohon keputusan dengan menggunakan algoritma C4.5 yang diolah menggunakan tools RapidMiner.

4) Evaluation: Evaluasi pola merupakan tahap untuk mengidentifikasi pola-pola menarik ke dalam knowledge based yang ditemukan. Pada tahap ini digunakan metode confusion matrix dengan menerapkan split validation untuk validasinya. Dengan menggunakan confusion matrix peneliti akan mendapatkan hasil accuracy, recall, dan precision dari model yang dihasilkan. Accuracy merupakan tingkat akurasi model antara nilai prediksi dan nilai aktual. Recall merupakan jangkauan algoritma terhadap nilai yang sebenarnya, sedangkan precision merupakan ketepatan algoritma terhadap nilai yang telah ditemukan algoritma

5) Presentation: Visualisasi dan penyajian pengetahuan mengenai metode yang digunakan untuk memperoleh pengetahuan yang diperoleh pengguna.

\section{HASIL DAN PEMBAHASAN}

\section{A. Percobaan 1}

Data yang digunakan dalam percobaan 1 ini adalah data kuisioner yang dibagikan kepada mahasiswa Universitas Sam Ratulangi angkatan 2013 sampai 2016 dengan jumlah 80 kuisioner. Dari pembagian 80 kuisioner ini diperoleh 26 data dengan ukt $0-3.000 .000,42$ dengan ukt $>3.000 .000-5.000 .000,7$ dengan $>5.000 .000$ - 
7.500.000, 2 data dengan ukt $>7.500 .000-11.000 .000$ dan

3 data dengan ukt $>11.000 .000$.

\section{1) Data Selection \& Cleaning}

Tabel 2. Data Hasil Seleksi

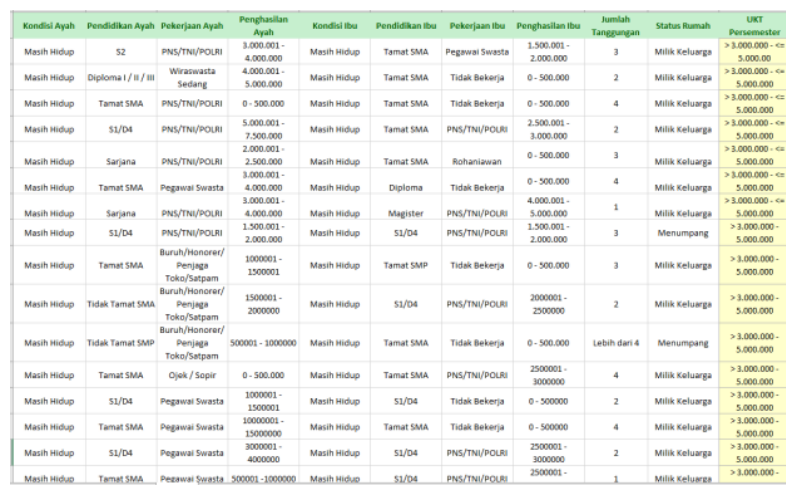

Pada tahap ini peneliti melakukan pembersihan dan

pemilihan data dari sekumpulan data yang didapatkan dari kuisioner yang telah diolah dengan menggunakan Microsoft excel. Data hasil seleksi adalah data yang akan digunakan dalam proses mining yang kemudian akan disimpan dalam satu file terpisah.

\section{2) Data Transformation}

Pada tahap ini data yang sudah diseleksi sebelumnya, ditransformasikan dari data numerik mejadi datastring seperti untuk atribut penghasilan ayah dan ibu dari nominal diubah menjadi golongan satu sampai dengan golongan duabelas sesuai dengan nominal yang telah ditentukan.

Tabel 3. Transformasi Data

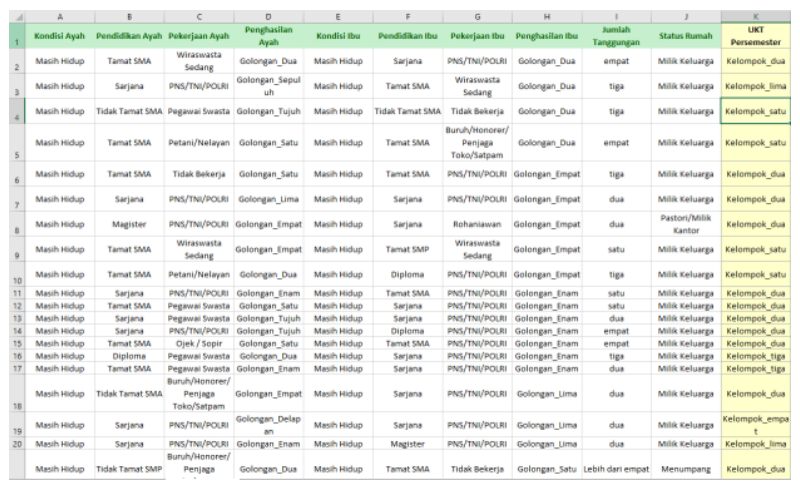

Kemudian disimpan dengan format .csv untuk diolah dengan bantuan toolsRapidMiner, yang digunakan untuk melakukan generalisasi/formulasi data yang sudah dikumpulkan.

\section{3) Data Mining}

Tahap ini adalah tahap dimana dilakukan proses klasifikasi data dengan menggunakan algoritma C4.5 dengan bantuan toolsRapidMiner. Berikut adalah proses pengolahan data untuk melihat hasil pohon keputusan dan aturan (rule).

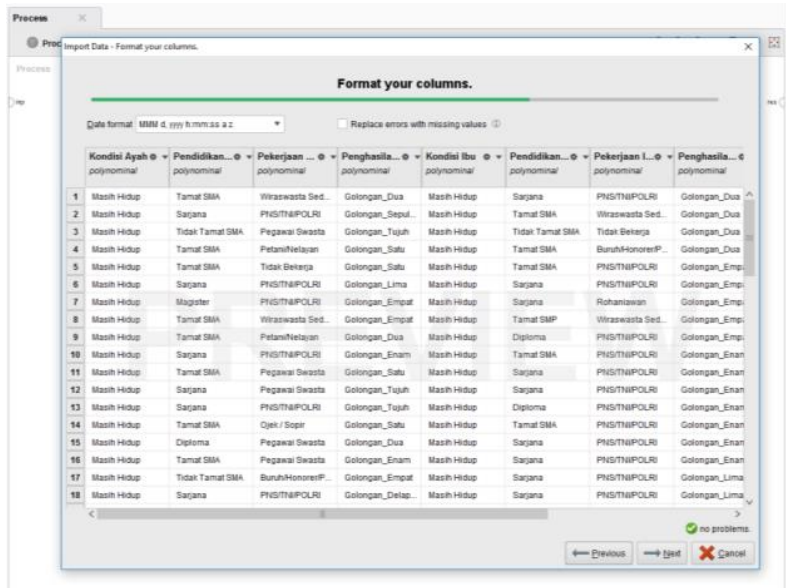

Gambar 3. Data yang diimport ke RapidMiner

Gambar 3 merupakan data yang telah siap diolah dengan algoritma $\mathrm{C} 4.5$ yang diimport dari penyimpanan. Sebelum data berhasil diimport pilihlah data yang akan menjadi kelas/label dari data hasil transformasi sebelumnya. Dalam hal ini, atribut yang menjadi kelas/label adalah atribut UKT.

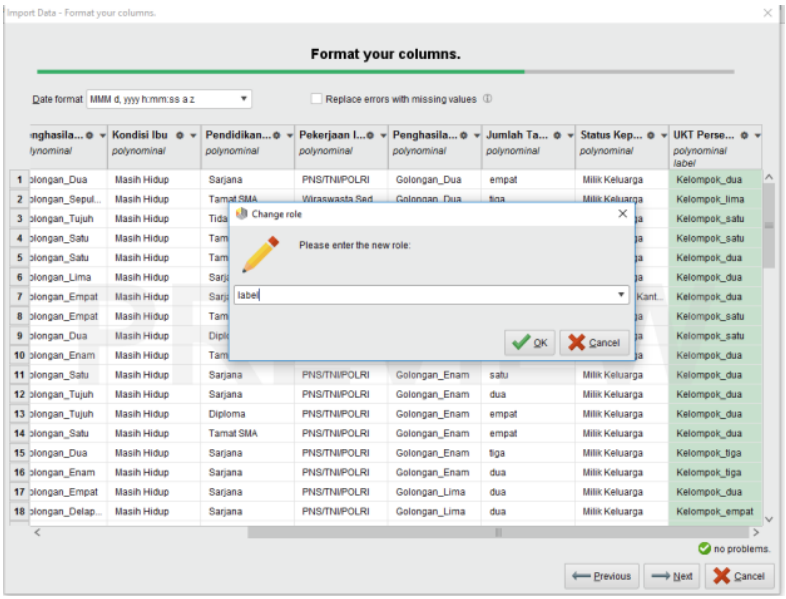

Gambar 4.Tampilan layout design RapidMiner

Setelah data berhasil diimport lalu data tersebut dimasukkan ke dalam layout process, kemudian pilih operator Decision Tree (Multiway). Pada operator Decision Tree pilih parameter gain ratio, kemudian dieksekusi dengan algoritma C4.5 pada RapidMiner, maka terbentuklah pohon keputusan seperti Gambar 5.

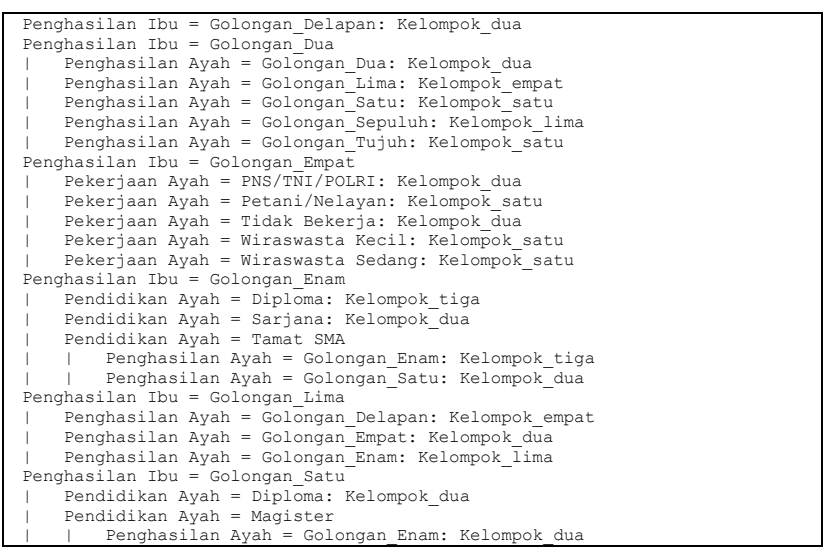




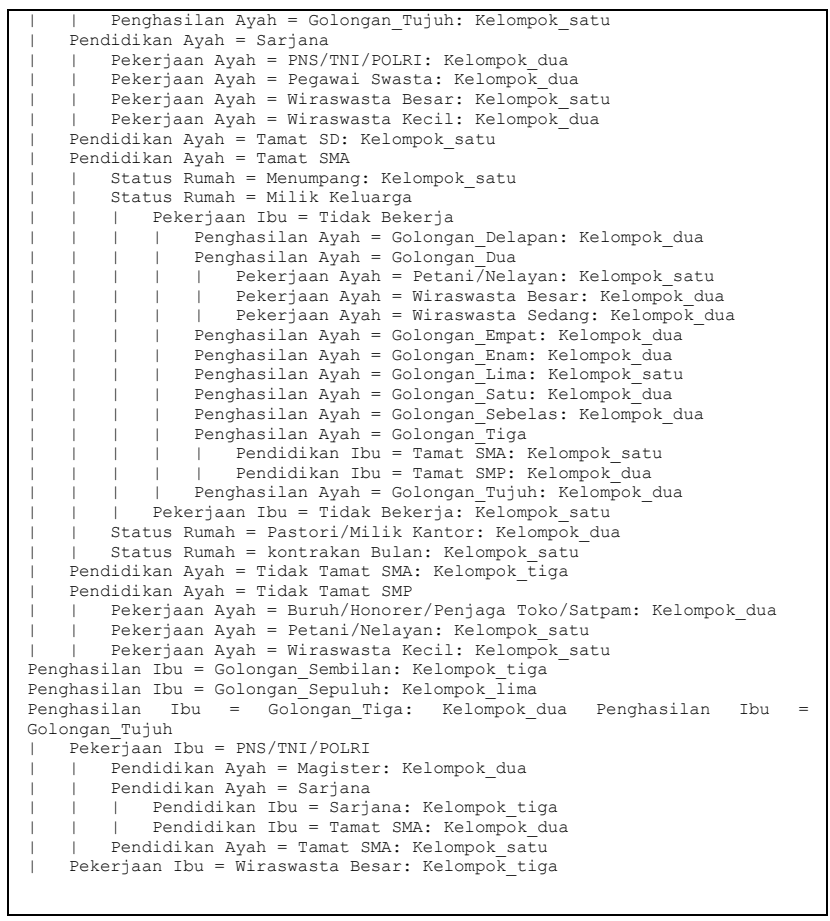

Gambar 5. Pohon Keputusan Percobaan 1

Pada Gambar 5 merupakan aturan yang didapatkan dari hasil pohon keputusan yang terbentuk. Dimana salah satu aturan yang ada pada pohon keputusan yaitu jika Penghasilan Ibu = Golongan_Delapan atau penghasilan $\mathrm{ibu}=4.000 .000$ sampai 5.000 .000 kelas UKT-nya Kelompok Dua atau >3.000.000 sampai 5.000.000.

\section{4) Evaluation}

Dalam tahap ini akan dilakukan validasi serta pengukuran keakuratan hasil yang dicapai oleh model. Pada tahap ini peneliti menggunakan metode confusion matrix untuk pengukuran akurasi model serta split validation untuk validasi dari model yang telah terbentuk.
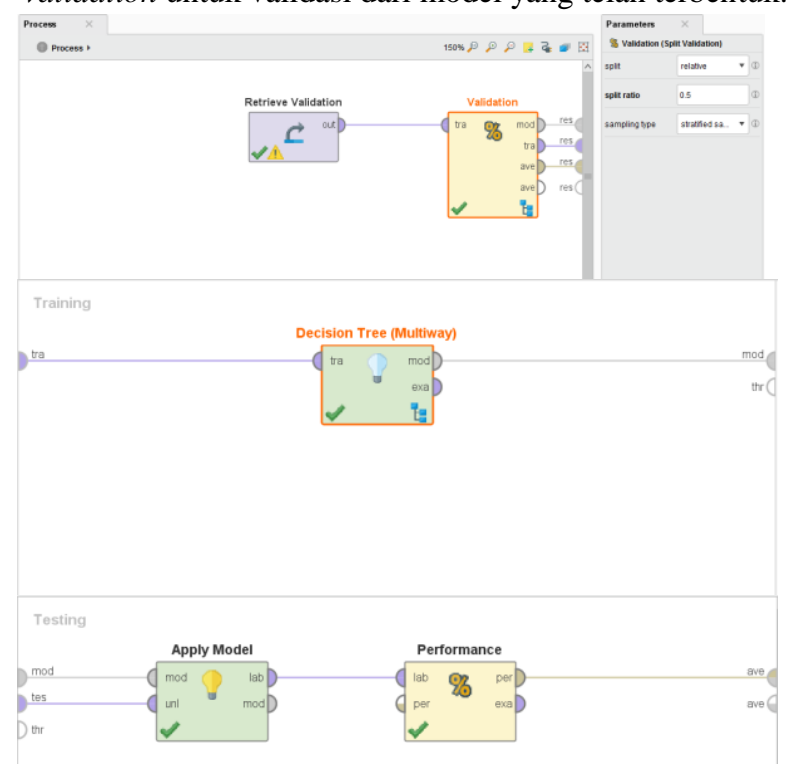

Gambar 6.Layout proses menemukan model dan validasi model.
Pengujian ini dilakukan dengan membagi total dari keseluruhan dataset menjadi data training dan data testing. Dimana, dataset yang digunakan untuk data training adalah sebesar $50 \%$ sedangkan untuk data testing sebesar $50 \%$.

Tabel 4.Confusion Matrix Model

\begin{tabular}{|c|c|c|c|c|c|c|}
\hline & $\begin{array}{l}\text { true } \\
\text { Kelompo } \\
\text { k_dua }\end{array}$ & $\begin{array}{l}\text { true } \\
\text { Kelompok } \\
\text { _lima }\end{array}$ & $\begin{array}{l}\text { true } \\
\text { Kelompok } \\
\text { _satu }\end{array}$ & $\begin{array}{l}\text { true } \\
\text { Kelompo } \\
\text { k_tiga }\end{array}$ & $\begin{array}{l}\text { true } \\
\text { Kelompok } \\
\text { _empat }\end{array}$ & $\begin{array}{l}\text { class } \\
\text { preci } \\
\text { sion }\end{array}$ \\
\hline $\begin{array}{l}\text { pred. } \\
\text { Kelompok } \\
\text { dua }\end{array}$ & 14 & 1 & 6 & 2 & 0 & $\begin{array}{c}60.87 \\
\%\end{array}$ \\
\hline $\begin{array}{l}\text { pred. } \\
\text { Kelompok } \\
\text { _lima }\end{array}$ & 2 & 0 & 1 & 0 & 1 & $\begin{array}{c}0.00 \\
\%\end{array}$ \\
\hline $\begin{array}{l}\text { pred. } \\
\text { Kelompok } \\
\text { _satu }\end{array}$ & 4 & 0 & 6 & 2 & 0 & $\begin{array}{c}50.00 \\
\%\end{array}$ \\
\hline $\begin{array}{l}\text { pred. } \\
\text { Kelompok } \\
\text { _tiga }\end{array}$ & 1 & 0 & 0 & 0 & 0 & $\begin{array}{c}0.00 \\
\%\end{array}$ \\
\hline $\begin{array}{l}\text { pred. } \\
\text { Kelompok } \\
\text { empat }\end{array}$ & 0 & 0 & 0 & 0 & 0 & $\begin{array}{c}0.00 \\
\%\end{array}$ \\
\hline class recall & $66.67 \%$ & $0.00 \%$ & $46.15 \%$ & $0.00 \%$ & $0.00 \%$ & \\
\hline
\end{tabular}

Performa yang didapatkan dalam validasi model ini adalah tingkat accuracy sebesar 50\%, nilai-rata-rata untuk recall sebesar $22.56 \%$ dan nilai rata-rata untuk precision sebesar $22.17 \%$.

\section{B. Percobaan 2}

Dalam percobaan 2 ini data yang digunakan adalah data kuisioner dengan jumlah 115 kuisioner. Dari pembagian kuisioner ini diperoleh 46 data dengan UKT 0 - 3.000.000, 53 dengan UKT >3.000.000 - 5.000.000, 11 dengan $>5.000 .000-7.500 .000,2$ data dengan UKT $>7.500 .000$ - 11.000.000 dan 3 data dengan UKT $>11.000 .000$. Kemudian lakukan proses seperti pada percobaan 1 yaitu proses selection\&cleaning data, proses transformation data, dan proses mining.

Setelah dilakukan proses mining maka terbentuklah satu pohon keputusan baru, dimana pada pohon keputusan tersebut didapatkan node akar pada atribut kondisi ibu. Dari pohon keputusan diatas didapatkan aturan kondisi dalam menentukan UKT seperti pada Gambar 7.

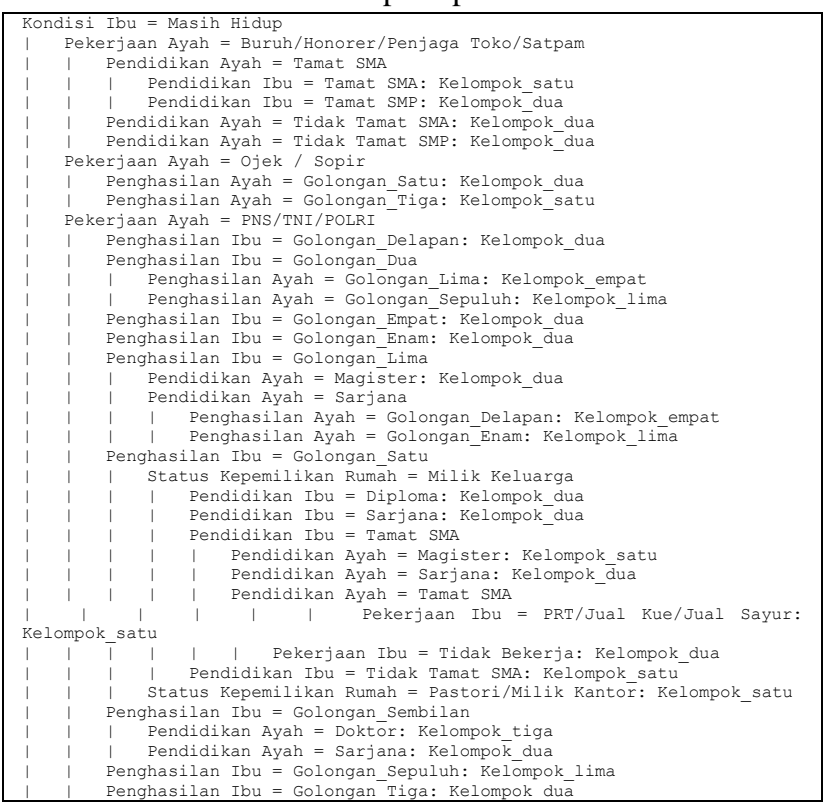




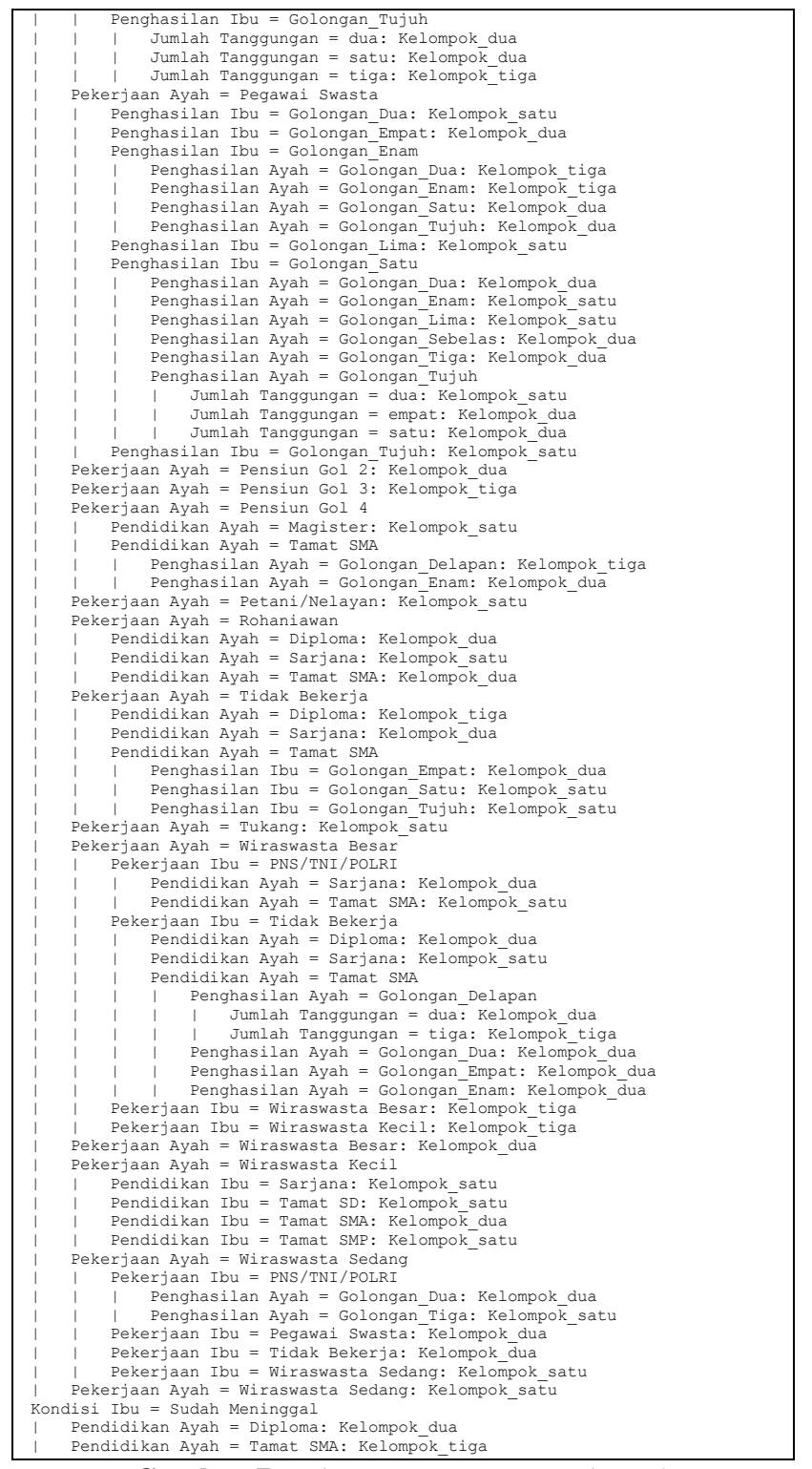

Gambar 7. Pohon Keputusan Percobaan 2

Pada Gambar 7 merupakan aturan yang didapatkan dari hasil pohon keputusan yang terbentuk. Dimana salah satu aturan yang ada pada pohon keputusan yaitu jika Kondisi Ibu = Masih Hidup dan Pekerjaan Ayah = Tukang maka kelas UKT-nya Kelompok Satu atau 0 sampai 3.000.000.

Seperti pada percobaan 1 dalam tahap ini akan dilakukan validasi serta pengukuran keakuratan hasil yang dicapai oleh model. Metode yang digunakan juga sama yaitu confusion matrix untuk pengukuran akurasi model serta split validation untuk validasi dari model yang telah terbentuk.

Tabel 5. Confusion Matrix Model 2

\begin{tabular}{|l|c|c|c|c|c|c|c|}
\hline \multicolumn{2}{|c|}{$\begin{array}{l}\text { true } \\
\text { Kelompo } \\
\text { k_dua }\end{array}$} & $\begin{array}{l}\text { true } \\
\text { Kelompok } \\
\text { _lima }\end{array}$ & $\begin{array}{l}\text { true } \\
\text { Kelompok } \\
\text { _satu }\end{array}$ & $\begin{array}{l}\text { true } \\
\text { Kelompo } \\
\text { k_tiga }\end{array}$ & $\begin{array}{l}\text { true } \\
\text { Kelompok } \\
\text { _empat }\end{array}$ & $\begin{array}{c}\text { class } \\
\text { preci } \\
\text { sion }\end{array}$ \\
\hline $\begin{array}{l}\text { pred. } \\
\text { Kelompok } \\
\text { _dua }\end{array}$ & 13 & 1 & 4 & 5 & 1 & $\begin{array}{c}54.17 \\
\%\end{array}$ \\
\hline $\begin{array}{l}\text { pred. } \\
\text { Kelompok } \\
\text { lima }\end{array}$ & 0 & 0 & 0 & 0 & 0 & $\begin{array}{c}0.00 \\
\%\end{array}$ \\
\hline
\end{tabular}

\begin{tabular}{|l|c|c|c|c|c|c|}
\hline $\begin{array}{l}\text { pred. } \\
\text { Kelompok } \\
\text { _satu }\end{array}$ & 9 & 1 & 17 & 0 & 0 & $\begin{array}{c}62.96 \\
\%\end{array}$ \\
\hline $\begin{array}{l}\text { pred. } \\
\text { Kelompok } \\
\text { _tiga }\end{array}$ & 4 & 0 & 2 & 0 & 0 & $\begin{array}{c}0.00 \\
\%\end{array}$ \\
\hline $\begin{array}{l}\text { pred. } \\
\text { Kelompok } \\
\text { _empat }\end{array}$ & 0 & 0 & 0 & 0 & 0 & 0.00 \\
\hline class recall & $50.00 \%$ & $0.00 \%$ & $73.91 \%$ & $0.00 \%$ & $0.00 \%$ & \\
\hline
\end{tabular}

Performa yang didapatkan dalam validasi model kedua ini adalah tingkat accuracy sebesar $52.63 \%$, nilairata-rata untuk recall sebesar $24.78 \%$ dan nilai rata-rata untuk precision sebesar $23.43 \%$. Dimana, pada pengujian ini rasio data yng digunakan dalam pengujian model yaitu $50 \%$ untuk data training dan $50 \%$ untuk data testing.

Tabel 6. Perbandingan hasil pengujian model.

\begin{tabular}{|c|c|c|c|}
\hline Jumlah Data & Accuracy & Recall & Presicion \\
\hline 80 & $50 \%$ & $22.56 \%$ & $22.17 \%$ \\
\hline 115 & $52.63 \%$ & $24.78 \%$ & $23.43 \%$ \\
\hline
\end{tabular}

Dari pengujian kedua model ini diketahui bahwa ada perbedaan dalam hasil pengujiannya. Pada pengujian model dengan jumlah data 80 didapatkan akurasi sebesar $50 \%$ sedangkan untuk pengujian dengan 115 data didapatkan nilai akurasi sebesar $52.63 \%$, dimana jumlah data berpengaruh dalam pengujian model.

C. Interface Aplikasi

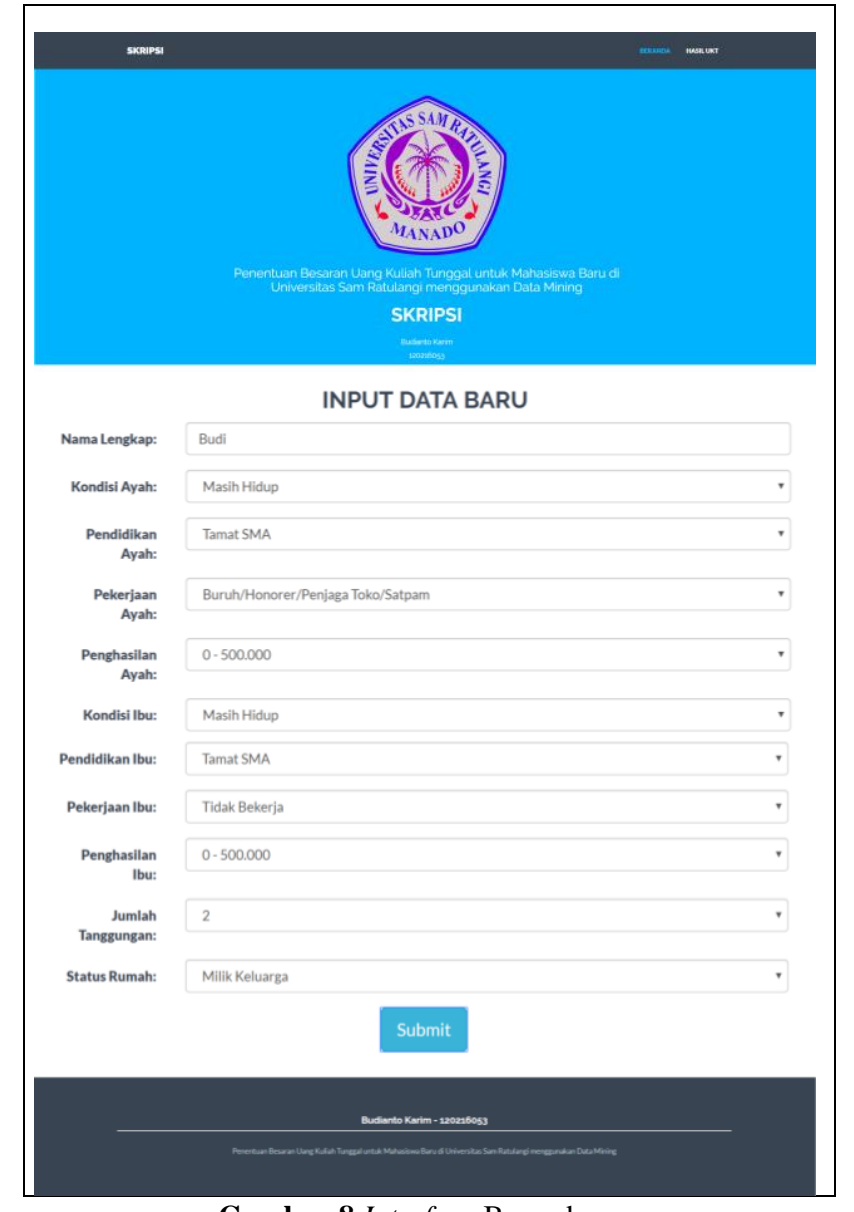

Gambar 8.Interface Beranda 
Berdasarkan proses pengolahan data menggunakan Algoritma C4.5 yang telah menghasilkan pohon keputusan dan rule yang telah terbentuk, selanjutnya akan diimplementasikan rule tersebut untuk membuat aplikasi penentuan besaran UKT.

Gambar 8 adalah interface beranda yang akan pertama muncul ketika sistem dijalankan. Pada tampilan ini pula akan ditampilkan form untuk mengetahui nilai UKT yang harus dibayar oleh mahasiswa baru ketika akan mendaftar dengan memasukkan data yang baru.

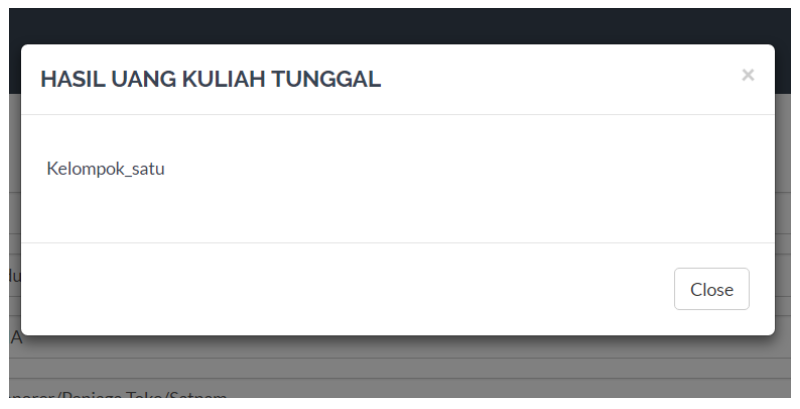

Gambar 9.Hasil UKT setelah memasukkan data baru

Gambar9 merupakan hasil kelompok UKT dari data mahasiswa baru dengan hasil UKT berada pada kelompok satu. Dimana, kelompok satu jumlah UKT-nya berada pada rentang $0-3.000 .000$.

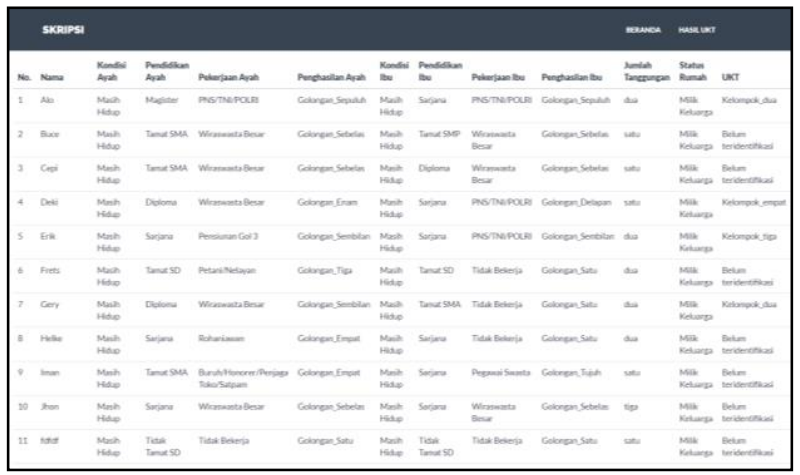

Gambar 10. Data telah tersimpan

Gambar 10 adalah tampilan data nama mahasiswa baru, kondisi orang tua, Pendidikan orang tua, pekerjaan orang tua, penghasilan orang tua, jumlah tanggungan, status kepemilikan rumah dan Hasil UKT yang telah diproses, dimana data tersebut didapatkan dari inputan yang dilakukan sebelumnya.

\section{PENUTUP}

\section{A. Kesimpulan}

Dari hasil penelitian yang telah dilakukan oleh peneliti, maka dapat disimpulkan bahwa aplikasi penentuan besaran uang kuliah tunggal (UKT) dapat diprediksi dengan memanfaatkan teknik data mining dengan menggunakan algoritma C4.5 untuk menentukan kelas dari uang kuliah tunggal yang telah ditentukan dengan data training yang telah diperoleh. Perbedaan pohon keputusan yang dihasilkan disebabkan oleh perbedaan jumlah data yang digunakan dalam membagun model.

Dari hasil pengujian dapat diketahui tingkat akurasi dari algoritma C4.5 menggunakan confusion matrix dengan jumlah data 80 menunjukkan bahwa tingkat akurasinya $50 \%$, yang terdiri dari $50 \%$ untuk data training dan 50\% untuk data testing. Sedangkan untuk hasil pengujian dengan jumlah data 115 menunjukkan bahwa tingkat akurasinya sebesar $52.63 \%$. Dimana jumlah data sangat berpengaruh dalam proses pembentukan model dan proses pengujian model.

\section{B. Saran}

Untuk meningkatkan kinerja dan menyempurnakan penelitian yang telah dibuat, peneliti memberikan saran sebagai berikut:

1. Penelitian ini dapat dikembangkan dengan menggabungkan atau membandingkan dengan algoritma klasifikasi lain untuk mendapatkan hasil prediksi yang lebih baik.

2. Sebaiknya jumlah data kuisioner ditambah, sehingga dapat diperoleh hasil akurasi yang lebih baik.

3. Aplikasi ini dapat dikembangkan menjadi otomatis dengan menerapkan algoritma C4.5 dalam aplikasi tanpa memperbaharui kembali aturan ketika ada data baru yang masuk.

\section{DAFTAR PUSTAKA}

[1] Achmad B. D. M. dan Slamat F. 2012. "Klasifikasi Data Karyawan untuk menentukan Jadwal Kerja menggunakan Metode Decision Tree ". Jurnal IPTEK 2012 Vol. 16 No.1.

[2] Aradea, Satriyo A., Ariyan Z., Yuliana A. 2011. "Penerapan Decision Tree untuk Penetuan Pola Data Penerimaan Mahasiswa Baru". Jurnal Penelitian Sitrotika 2011 Vol. 7 No. 1.

[3] C. Dennis Aprilla, Baskoro Donny Aji, Ambarwati Lia, Wicaksana I Wayan Simri. 2013. "Belajar Data Mining dengan RapidMiner". Jakarta.

[4] DefiyantiS. dan Pardede D. L. 2010. "Perbandingan Kinerja Algoritma ID3 dan C4.5 dalam Klasifikasi Spam-Mail". Universitas Gunadarma.

[5] Han J, Kamber M. and Pei J. 2011. "Data Mining: Concepts and Technique". Waltham: Morgan Kaufmann.

[6] Julianto, W, Yunitari R dan Shopan M. K. 2014. "Algoritma C4.5 Untuk Penilaian Kinerja Karyawan". Universitas Trunojoyo Madura. SCAN vol IX no. 2. 
[7] Prasetyo E. 2014. "Data Mining: Mengolah Data menjadi Informasi menggunakan MatLab. Andi Offset: Yogyakarta.

[8] Raditya A. 2012. "Implementasi data mining classification untuk mencari pola prediksi hujan dengan menggunakan algoritma C4.5". Jurusan Teknik Informatika Fakultas Teknologi Industri Universitas Gunadarma.

[9] Republik Indonesia. 2013. "Peraturan Menteri Pendidikan dan Kebudayaan No. 55 Tahun 2013 Tentang Biaya Kuliah Tunggal dan Uang Kuliah Tunggal pada Perguruan Tinggi Negeri di Lingkungan Kementerian Pendidikan dan Kebudayaan. Kementerian Pendidikan dan Kebudayaan Republik Indonesia. Jakarta

[10] Ridwan, M., Suyono, H., \& Sarosa, M. 2013. "Penerapan Data Mining Untuk Evaluasi Kinerja Akademik Mahasiswa Menggunakan Algoritma Naive Bayes Classifier". Jurnal EECCIS, 7(1), 5964.

[11] Siallagan T. F. P. 2015. "Pencarian Nasabah dengan Menggunakan Data Mining dan Algoritma C4.5 Koperasi Maduma Subang,"JuTISI 2015 Vol. 1

[12] Tanjung P. Yudhi. 2016. "Penentuan Daya Listrik Rumah Tangga Mengunakan Metode Decision Tree". Skripsi Teknik Informatika Universitas Sam Ratulangi. Manado.
TENTANG PENULIS

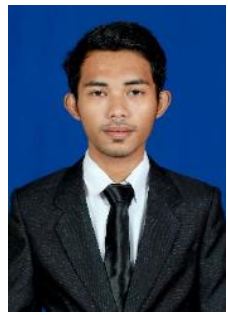

Budianto Karim, lahir di Manado pada tanggal 23 April 1995. Penulis menempuh Pendidikan secara berturut-turut di TK Cokroaminoto Manado (2000-2001), SD Negeri 13 Manado (2001-2006), SMP

Cokroaminoto Manado (2006-2009), dan lulus dari SMK Negeri 2 Manado dengan Kompetensi Keahlian Multimedia (2009-2012).

Pada tahun 2012, penulis melanjutkan studi di Program Studi Informatika, Jurusan Teknik Elektro, Fakultas Teknik, Universitas Sam Ratulangi. Selama masa kuliah, penulistelah menjalani kerja praktek di ELFAH Hotel Manado, serta mengikuti kegiatan KuliahKerja Terpadu di Desa Bulo, Kecamatan Wori, Kabupaten Minahasa Utara.Penulis mendapatkan sertifikasi dari Badan Nasional Sertifikasi Profesi (BNSP) untuk Junior Multimedia oleh Lembaga Sertifikasi Profesi Teknologi Informasi dan Komunikasi (LSP TIK) Surabaya.Selama kuliah penulis pernah tergabung dalam organisasi kemahasiswaan yaitu, Badan Tadzkir Fakultas Teknik Universitas Sam Ratulangi, Unsrat IT Community dan Himpunan Mahasiswa Elektro FTUnsrat. Penulis menyelesaikan studi di Program Studi Informatika, Jurusan Teknik Elektro, Fakultas Teknik, Universitas Sam Ratulangi pada 8 Juni 2017. 